\title{
Productivity of Spring Wheat Using Megamix Mineral Fertilizers
}

\author{
Vasily Vasin*, Alexey Burunov, Natalia Vasina, Anatoly Strizhakov \\ Samara State Agrarian University, 2 Uchebnaya Str., Ust-Kinelsky village, Kinel, Samara Region, 446442, Russian Federation
}

\begin{abstract}
The paper shows the research results related to the development of methods to increase the yield of spring wheat using Megamix liquid mineral fertilizers in the presowing treatment of seeds, treatment of crops on vegetation when introducing mineral fertilizers in seedbed preparation in the forest-steppe conditions of the Middle Volga region. The studies were carried out on the experimental field of Samara State University in 2017-2020. During the three-factor field experiment, dry matter accumulation and photosynthetic activity were evaluated with the analysis of photosynthetic potential and net productivity of photosynthesis. It was established that the best indicators are formed on versions with the treatment of seeding material with Megamix Seeds or Megamix Profi agents with subsequent double treatment on vegetation with Megamix Profi in the amount of 0.51/ha (in the tillering phase) + Megamix Nitrogen in the amount of $0.51 /$ ha (in the flag leaf phase) against the background of ${ }_{N_{32}} \mathrm{P}_{32} \mathrm{~K}_{32}$ fertilizer application. The application of Megamix agents in the system of seed treatment + treatment of crops with Megamix stimulating agents provides the maximum accumulation of dry matter in the version of Megamix Seeds treatment and the treatment of crops with a mixture of Megamix Profi + Megamix Nitrogen $-591.9 \mathrm{~g} / \mathrm{m}$ on soft crops and $622.6 \mathrm{~g} / \mathrm{m}^{2}$ - durum wheat against the background of $\mathrm{N}_{32} \mathrm{P}_{32} \mathrm{~K}_{32}$ application. The maximum photosynthetic potential of $0.968 \ldots 1.091$ million $\mathrm{m}^{2} / \mathrm{ha}$ per day is formed in these versions, and, consequently, the maximum yields with values of $3.73 \mathrm{t} / \mathrm{ha}$ on soft wheat crops and $3.44 \mathrm{t} / \mathrm{ha}$ on durum wheat crops. It was found that the use of liquid mineral fertilizers on all versions of the experiment reliably increases the yield of spring wheat.
\end{abstract}

\section{Introduction}

Spring wheat is the most important feed grain. It is widely used in the Volga region, in the Urals, in Western and Eastern Siberia. About $10 \%$ of its crops are represented by durum wheat (T. durum Desf.), the rest by soft wheat (T. aestivum L.). On average, dry matter of soft wheat grain contains $13.9 \%$ protein, $79.9 \%$ carbohydrates, $2 \%$ fat, $1.9 \%$ ash and $2.3 \%$ fiber, while the durum wheat contains $16 \%$ protein, $77.4 \%$ carbohydrates, $2.1 \%$ fat, $2 \%$ ash and $2.4 \%$ fiber. Soft wheat flour is widely used in the baking and confectionery industries, durum - for the production of pasta and semolina. Wastes of flour-milling industry (bran, flour dust), post-harvest cleaning (fine grain), as well as straw and chaff are considered a good feed for animals $[15,19,20]$.

The increase in the sowing area of soft and durum wheat varieties is often not economically justified due to the use of very expensive cultivation technologies and low purchasing prices without taking into account the labor intensity of its cultivation, including in the arid climate of the forest-steppe of the Middle Volga region $[18,4,16]$.

In modern conditions, the use of stimulating agents is becoming increasingly popular in spring wheat growing industry. This is caused by the fact that modern stimulants have a diverse spectrum of action and, due to their saturated composition, participate in all vital processes in plants. Hence, they have a great influence on yield enhancement, improve the quality of spring wheat grains, stimulate plants in combating adverse environmental conditions, pests and diseases $[14,7,8]$.

One way to solve the problem of increasing the production of soft and durum wheat grains is to use less expensive, effective growing technologies that use stimulating agents, including in the form of liquid mineral fertilizers with a high content of macro-, meso-, and micronutrients. The use of such agents has a significant impact on the formation of a balanced high quality harvest. This is primarily caused by the fact that the macro- and microelements contained in the agents are an indispensable source of nutrition, contribute to increasing plant immunity, reducing the impact of stress from the use of pesticides and adverse weather conditions, including drought $[11,3,4,5,1,15,10]$.

\section{Materials and Methods}

During the three-factor field experiment, the increase in dry matter was determined; photosynthetic potential and net photosynthesis productivity (NPP) were calculated. Harvesting was carried out in the firm ripe stage $(\mathrm{BBCH}$ 99). Statistical processing of yield data was carried out

\footnotetext{
* Corresponding author: Vasin_VG@ssaa.ru
} 
by the dispersion method (according to B.A. Dospekhov) [6].

The three-factor experiment design provided for the following:

1. Three levels of mineral nutrition (factor A): Control (without fertilizers), application of $\mathrm{N}_{16} \mathrm{P}_{16} \mathrm{~K}_{16}$ fertilizers, and application of $\mathrm{N}_{32} \mathrm{P}_{32} \mathrm{~K}_{32}$;

2. Seed treatment (factor B): Control (without treatment) - (K), treatment with Megamix Seeds $21 / \mathrm{t}$ (MS), treatment with Megamix Profi 2 1/t (factor B); (MP);

3. Vegetation treatment (factor C): Control (without treatment), treatment with Megamix Profi in the tillering phase 0.5 1/ha - (MP), treatment with Megamix Profi in the tillering phase $0.5 \mathrm{l} / \mathrm{ha}+$ treatment with Megamix Nitrogen 0.5 1/ha in the flag leaf phase (factor C) - (MP $+\mathrm{MN})$

In the comparative assessment of soft and durum wheat, the Kinelskaya Niva and Bezenchukskaya Zolotistaya varieties were included in the register for the 07 agroclimatic region.

Kinelskaya Niva soft spring wheat variety is midseason, resistant to showering, is well threshed. It is characterized by harmonious growth and development of plants during vegetation, high resistance to brown rust, powdery mildew and tolerance to root rots. The thousand-kernel weight is 34-36 g, natural weight - 768$807 \mathrm{~g} / \mathrm{l}$. Its baking indicators correspond to a strong variety. The protein content in the grain is $18.5 \%$, raw gluten is $36 \%$, at gluten deformation index of 75-100 units. The average perennial yield of the variety is 28 $\mathrm{c} / \mathrm{ha}$, the potential productivity on increased agrophone is up to $53 \mathrm{c} / \mathrm{ha}$.

Bezenchukskaya Zolotistaya variety. The thousandkernel weight is 45-49 g. The average yield in the Middle Volga region is $22.9 \mathrm{c} / \mathrm{ha}$. This is a mid-season variety, the growing season is 77-88 days, ripens 1-2 days later than the Bezenchukskaya Steppe variety. This variety is resistant to flooding and drought. It is also moderately resistant to brown rust and head smut. In field conditions it was slightly affected by a dust brand and strongly by powdery mildew [9, 17].

All studies were carried out according to the generally accepted methodology [6].

The following agents were used in the experiments:

Megamix Seeds is a liquid mineral fertilizer for pretreatment of seeds based on micro- and macroelements.

It contains microelements, g/l: $\mathrm{B}-4.6, \mathrm{Cu}-33, \mathrm{Zn}-$ $31, \mathrm{Mn}-3.0, \mathrm{Co}-2.8, \mathrm{Mo}-7.0, \mathrm{Cr}-0.5, \mathrm{Se}-0.1, \mathrm{Ni}-$ 0.1 ; macroelements, $\mathrm{g} / \mathrm{l}: \mathrm{N}-58, \mathrm{P}-6, \mathrm{~K}-58$; mesoelements: $\mathrm{Fe}-4.0, \mathrm{Mg}-22, \mathrm{~S}-50$ [12].

Megamix Nitrogen is a liquid nitrogen fertilizer for foliar dressing with a rich content of microelements.

It contains microelements, g/l: $\mathrm{B}-0.8, \mathrm{Cu}-2.5, \mathrm{Zn}$ - 2.5, Mn - 1.0, Mo - 0.6, Co - 0.12, Se - 0.06; macroelements, g/l: $\mathrm{N}-116$; mesoelements: $\mathrm{Mg}-6, \mathrm{Fe}$ $-1.0, \mathrm{~S}-8$ [13].

Megamix Profi is a liquid mineral fertilizer with a rich content of macro-, meso- and microelements, which is used for seed treatment and foliar dressing during vegetation.
It contains microelements, g/l: $\mathrm{B}-1.7, \mathrm{Cu}-12, \mathrm{Zn}-$ 11, Mn - 2.5, Mo - 1.7, Co - 0.5, Se - 0.06; macroelements, g/l: $\mathrm{N}-2.5$; mesoelements: $\mathrm{Fe}-2.0$, $\mathrm{Mg}-17, \mathrm{~S}-25$.

The purpose of the study is to increase the yield of spring wheat when using liquid mineral fertilizers Megamix in the system of presowing treatment and processing of seeds on vegetation when applying $\mathrm{N}_{16} \mathrm{P}_{16} \mathrm{~K}_{16}, \quad \mathrm{~N}_{32} \mathrm{P}_{32} \mathrm{~K}_{32}$ fertilizers in the forest-steppe conditions of the Middle Volga region.

Research tasks: to assess the peculiarities of the growth, development and photosynthetic activity of plants, to evaluate the amount of crop with different application of Megamix liquid mineral fertilizers against the background of $\mathrm{N}_{16} \mathrm{P}_{16} \mathrm{~K}_{16}$ and $\mathrm{N}_{32} \mathrm{P}_{32} \mathrm{~K}_{32}$ fertilizers in soil preparation.

\section{Results and Discussion}

Meteorological conditions that develop during the growth and development of crops have a direct impact on plant productivity [3].

For the entire period of study (2017-2020) there were no identical weather conditions. Thus, in 2017, wheat growth and development took place with good humidification and favorable temperatures. Weather conditions during vegetation in 2018 and in 2019 were unfavorable. First of all, this is caused by the small amount of precipitation during the growing season.

In 2020, weather conditions were quite favorable for the cultivation of spring wheat. The air temperature was at the level of average long-term data, and precipitation in June helped plants significantly gain mass and increase leaf area, which positively affected the final results, i.e. the yield.

The intensity of growth of the tops of spring wheat largely depends on meteorological conditions, as well as on the use of the Megamix system of liquid mineral fertilizers as stimulating agents.

In our research, we study the effects of liquid mineral fertilizers: Megamix Seeds, Megamix Profi and Megamix Nitrogen with an assessment of the intensity of photosynthesis, and hence, the accumulation of dry matter in plants. The tendency of dry matter accumulation intensity between spring wheat plants and mineral nutrition is evident (Table 1).

On the versions of soft spring wheat, where vegetation treatments were carried out, the best was sowing with double treatment of Megamix Profi 0.5 1/ha + Megamix Nitrogen 0.5 1/ha against the background of $\mathrm{N}_{32} \mathrm{P}_{32} \mathrm{~K}_{32}$, with the highest indicators when treating seeds with Megamix Seeds - $591.9 \mathrm{~g} / \mathrm{m}^{2}$. In the remaining versions, this figure was lower, but generally higher than without treatments (Table 1).

The nature of accumulation of dry organic matter for durum wheat crops largely coincides with soft wheat, however, in the conditions of the changed climate, the level of indicators is higher for the early yellowing stage $(83 \mathrm{BBCH})$. The maximum accumulation of the dry matter - $622.6 \mathrm{~g} / \mathrm{m}^{2}-$ is still provided against the background of the $\mathrm{N}_{32} \mathrm{P}_{32} \mathrm{~K}_{32}$ treatment of seeds with 
Megamix Seeds and Megamix Profi + Megamix Nitrogen (Table 1).

Photosynthetic activity of plants is closely related to biological peculiarities and undergoes changes depending on the stages of organogenesis and growth conditions, among which the Megamix stimulant treatment system occupies an important place [2].
At the beginning of plant development there is a gradual accumulation of tops and an increase in the leaf surface area of spring wheat. During this period, the energy of photosynthetically active radiation (PAR) is effectively used - organic matter is accumulated and the level of photosynthetic potential increases

Table 1. Photosynthetic potential and net productivity of spring wheat photosynthesis, average for 2017-2020

\begin{tabular}{|c|c|c|c|c|c|c|c|c|}
\hline \multirow{2}{*}{\multicolumn{3}{|c|}{ Version }} & \multicolumn{3}{|c|}{ Soft wheat } & \multicolumn{3}{|c|}{ Durum wheat } \\
\hline & & & \multirow{2}{*}{$\begin{array}{c}\begin{array}{c}\text { photosynthetic } \\
\text { potential, } \\
\text { mln } \mathrm{m}^{2} / \text { ha } \cdot \text { days }\end{array} \\
\sum\end{array}$} & \multirow{2}{*}{\begin{tabular}{|c}
$\begin{array}{c}\text { net productivity } \\
\text { of } \\
\text { photosynthesis, } \\
\mathrm{g} / \mathrm{m}^{2} \cdot \text { days }\end{array}$ \\
avg \\
\end{tabular}} & \multirow{2}{*}{$\begin{array}{c}\begin{array}{c}\text { dry matter, } \\
\mathrm{g} / \mathrm{m}^{2} \\
(83 \mathrm{BBCH})\end{array} \\
\text { avg } \\
\end{array}$} & \multirow{2}{*}{ 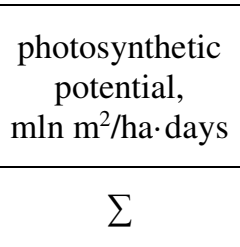 } & \multirow{2}{*}{ 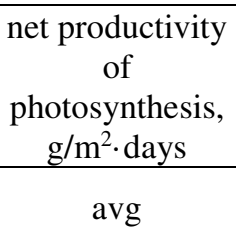 } & \multirow{2}{*}{$\begin{array}{c}\begin{array}{c}\text { lry matter, } \\
\mathrm{g} / \mathrm{m}^{2} \\
(83 \mathrm{BBCH})\end{array} \\
\text { avg } \\
\end{array}$} \\
\hline $\begin{array}{l}\text { NPK } \\
\text { dose }\end{array}$ & $\begin{array}{c}\text { Seed } \\
\text { treatment }\end{array}$ & $\begin{array}{l}\text { Vegetation } \\
\text { treatment }\end{array}$ & & & & & & \\
\hline \multirow{9}{*}{ 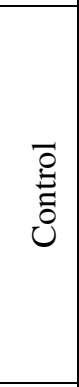 } & \multirow{3}{*}{$\mathrm{C}$} & $\mathrm{C}$ & 0.666 & 7.58 & 448.0 & 0.602 & 10.02 & 500.9 \\
\hline & & MP & 0.774 & 7.30 & 469.5 & 0.671 & 9.79 & 510.9 \\
\hline & & $\mathrm{MP}+\mathrm{MN}$ & 0.842 & 7.39 & 499.2 & 0.849 & 6.51 & 466.5 \\
\hline & \multirow{3}{*}{ MS } & $\mathrm{C}$ & 0.658 & 8.31 & 470.2 & 0.594 & 10.24 & 514.0 \\
\hline & & MP & 0.794 & 7.09 & 469.8 & 0.653 & 10.13 & 555.3 \\
\hline & & $\mathrm{MP}+\mathrm{MN}$ & 0.908 & 6.33 & 480.9 & 0.790 & 7.90 & 511.2 \\
\hline & \multirow{3}{*}{ MP } & $\mathrm{C}$ & 0.719 & 7.33 & 455.5 & 0.644 & 8.80 & 474.5 \\
\hline & & MP & 0.792 & 7.26 & 465.0 & 0.709 & 8.92 & 515.5 \\
\hline & & $\mathrm{MP}+\mathrm{MN}$ & 0.957 & 7.05 & 529.5 & 0.851 & 8.53 & 556.2 \\
\hline \multirow{9}{*}{ 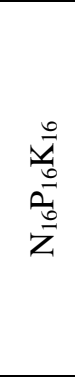 } & \multirow{3}{*}{$\mathrm{C}$} & $\mathrm{C}$ & 0.748 & 7.05 & 465.3 & 0.676 & 8.33 & 486.2 \\
\hline & & MP & 0.813 & 7.45 & 510.3 & 0.803 & 7.00 & 496.2 \\
\hline & & $\mathrm{MP}+\mathrm{MN}$ & 0.891 & 7.52 & 555.0 & 0.931 & 7.11 & 556.0 \\
\hline & \multirow{3}{*}{ MS } & $\mathrm{C}$ & 0.715 & 8.07 & 481.6 & 0.662 & 9.34 & 503.5 \\
\hline & & MP & 0.824 & 7.54 & 515.4 & 0.776 & 8.09 & 534.3 \\
\hline & & $\mathrm{MP}+\mathrm{MN}$ & 0.959 & 7.70 & 585.0 & 0.981 & 8.12 & 610.9 \\
\hline & \multirow{3}{*}{ MP } & $\mathrm{C}$ & 0.748 & 7.20 & 450.2 & 0.724 & 8.84 & 495.8 \\
\hline & & MP & 0.835 & 7.14 & 496.2 & 0.873 & 6.95 & 516.8 \\
\hline & & $\mathrm{MP}+\mathrm{MN}$ & 0.993 & 7.10 & 567.6 & 0.983 & 7.15 & 573.8 \\
\hline \multirow{9}{*}{ 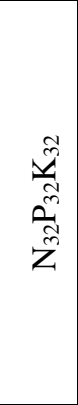 } & \multirow{3}{*}{$\mathrm{C}$} & $\mathrm{C}$ & 0.705 & 7.60 & 442.1 & 0.746 & 7.92 & 501.2 \\
\hline & & MP & 0.807 & 6.97 & 464.1 & 0.815 & 7.03 & 494.2 \\
\hline & & $\mathrm{MP}+\mathrm{MN}$ & 1.001 & 7.06 & 562.7 & 0.966 & 6.96 & 585.9 \\
\hline & \multirow{3}{*}{ MS } & $\mathrm{C}$ & 0.742 & 6.94 & 439.0 & 0.726 & 8.26 & 496.2 \\
\hline & & MP & 0.854 & 7.04 & 488.3 & 0.881 & 7.14 & 540.3 \\
\hline & & $\mathrm{MP}+\mathrm{MN}$ & 1.031 & 7.13 & 591.9 & 0.968 & 7.74 & 622.6 \\
\hline & \multirow{3}{*}{ MP } & $\mathrm{C}$ & 0.770 & 7.33 & 464.8 & 0.698 & 7.96 & 469.3 \\
\hline & & MP & 0.908 & 6.64 & 464.8 & 0.774 & 7.69 & 526.6 \\
\hline & & $\mathrm{MP}+\mathrm{MN}$ & 0.996 & 9.70 & 497.1 & 0.913 & 7.41 & 580.9 \\
\hline
\end{tabular}

${ }^{*} \mathrm{C}$ - Control; MS - Megamix Seeds; MP - Megamix Profi; MN - Megamix Nitrogen.

In versions where Megamix liquid mineral fertilizers are used, the photosynthetic potential is higher than in control versions (without seed treatment). It is clear that the treatment of seeds with Megamix agents containing microelements contributes to an increase in the photosynthetic potential of crops under the influence of the photochemical activity of chloroplasts.

The highest indicators are noted on the version of joint treatment of seeds with Megamix Seeds and double vegetation treatment with Megamix Profi and Megamix Nitrogen against the background of applied $\mathrm{N}_{32} \mathrm{P}_{32} \mathrm{~K}_{32}$ fertilizers. Here, the total photosynthetic potential reaches 1.031 million $\mathrm{m}^{2} / \mathrm{ha}$-days for soft wheat and
0.968 million $\mathrm{m}^{2} / \mathrm{ha} \cdot$ days for durum wheat crops (Table 1). High indicator is also achieved by wheat crops against the background of $\mathrm{N}_{16} \mathrm{P}_{16} \mathrm{~K}_{16}$ fertilizer application. Here, when treating crops with Megamix Profi + Megamix Nitrogen against the background of treating seeds with Megamix Seeds, a photosynthetic potential of 0.959 million $\mathrm{m}^{2} /$ ha days is formed for soft wheat against the background of treating seeds with Megamix Profi - 0.993 million $\mathrm{m}^{2} /$ ha days. For durum wheat crops, these versions also turned out to be better with values of 0.981 and 0.983 million $\mathrm{m}^{2} /$ ha days.

The studies revealed that the total level of accumulation of dry organic matter for durum wheat 
crops is higher, which is caused by higher indicators of net photosynthesis productivity. Moreover, without the use of fertilizers, the NPP was within 7.90..10.24 $\mathrm{g} / \mathrm{m}^{2}$. days against the background of the application of $\mathrm{N}_{16} \mathrm{P}_{16} \mathrm{~K}_{16}$ fertilizers - 6.95...9.34 $\mathrm{g} / \mathrm{m}^{2}$. days; against the background of $\mathrm{N}_{32} \mathrm{P}_{32} \mathrm{~K}_{32}-6.96 \ldots 8.26 \mathrm{~g} / \mathrm{m}^{2}$. days. This is a higher level of indicators than for soft wheat crops $6.33 \ldots 8.31 \mathrm{~g} / \mathrm{m}^{2}$. days in control and 7.10...8.07 $\mathrm{g} / \mathrm{m}^{2}$. days $\left(\mathrm{N}_{16} \mathrm{P}_{16} \mathrm{~K}_{16}\right), 6.64 \ldots 9.70 \mathrm{~g} / \mathrm{m}^{2}$. days against the background of $\mathrm{N}_{32} \mathrm{P}_{32} \mathrm{~K}_{32}$ fertilizer application.
The amount of crop is one of the main indicators of its value. To a large extent, the productivity of crops depends on the cultivated crop, the use of the Megamix stimulating system, and weather conditions.

On average in four years of study it was established that the presowing fertilizing at a dose of $\mathrm{N}_{16} \mathrm{P}_{16} \mathrm{~K}_{16}$ and $\mathrm{N}_{32} \mathrm{P}_{32} \mathrm{~K}_{32}$ increases productivity from 2.30 to $2.69 \mathrm{t} / \mathrm{ha}$ and $3.23 \mathrm{t} / \mathrm{ha}$, which provides reliable increase of 0.39 and $0.93 \mathrm{t} / \mathrm{ha}$ for soft wheat and from 2.48 to $2.77 \mathrm{t} / \mathrm{ha}$ and $3.06 \mathrm{t} / \mathrm{ha}$ with reliable increase of 0.29 and $0.52 \mathrm{t} / \mathrm{ha}$ for durum wheat crops (Table 2, 3).

Table 2. Yield of soft spring wheat, 2017-2020

\begin{tabular}{|c|c|c|c|c|c|}
\hline \multicolumn{3}{|c|}{ Version } & \multirow[b]{2}{*}{ Received, t/ha } & \multirow[b]{2}{*}{$\begin{array}{l}\text { Average for seed } \\
\text { treatment, } \mathrm{t} / \mathrm{ha}\end{array}$} & \multirow[b]{2}{*}{$\begin{array}{c}\text { Average for } \\
\text { fertilizer rate, } \mathrm{t} / \mathrm{ha}\end{array}$} \\
\hline Fertilizer rate $(\mathrm{A})$ & $\begin{array}{c}\text { Seed } \\
\text { treatment } \\
\text { (B) }\end{array}$ & $\begin{array}{l}\text { Vegetation } \\
\text { treatment } \\
\text { (C) }\end{array}$ & & & \\
\hline \multirow{9}{*}{ 荇 } & \multirow{3}{*}{$\mathrm{C}$} & $\mathrm{C}$ & 2.00 & \multirow{3}{*}{2.15} & \multirow{9}{*}{2.30} \\
\hline & & MP & 2.16 & & \\
\hline & & $\mathrm{MP}+\mathrm{MN}$ & 2.30 & & \\
\hline & \multirow{3}{*}{ MS } & $\mathrm{C}$ & 2.21 & \multirow{3}{*}{2.39} & \\
\hline & & MP & 2.40 & & \\
\hline & & $\mathrm{MP}+\mathrm{MN}$ & 2.58 & & \\
\hline & \multirow{3}{*}{ MP } & $\mathrm{C}$ & 2.14 & \multirow{3}{*}{2.35} & \\
\hline & & MP & 2.39 & & \\
\hline & & $\mathrm{MP}+\mathrm{MN}$ & 2.52 & & \\
\hline \multirow{9}{*}{ 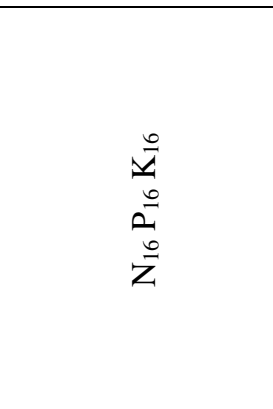 } & \multirow{3}{*}{$\mathrm{C}$} & $\mathrm{C}$ & 2.28 & \multirow{3}{*}{2.51} & \multirow{9}{*}{2.69} \\
\hline & & MP & 2.49 & & \\
\hline & & $\mathrm{MP}+\mathrm{MN}$ & 2.77 & & \\
\hline & \multirow{3}{*}{ MS } & $\mathrm{C}$ & 2.49 & \multirow{3}{*}{2.77} & \\
\hline & & MP & 2.68 & & \\
\hline & & $\mathrm{MP}+\mathrm{MN}$ & 3.14 & & \\
\hline & \multirow{3}{*}{ MP } & $\mathrm{C}$ & 2.45 & \multirow{3}{*}{2.78} & \\
\hline & & MP & 2.75 & & \\
\hline & & MP+MN & 3.15 & & \\
\hline \multirow{9}{*}{$\begin{array}{l}\tilde{\tilde{z}} \\
\tilde{n} \\
\tilde{n}^{\tilde{z}} \\
\tilde{z}\end{array}$} & \multirow{3}{*}{$\mathrm{C}$} & $\mathrm{C}$ & 2.66 & \multirow{3}{*}{2.92} & \multirow{9}{*}{3.23} \\
\hline & & MP & 3.00 & & \\
\hline & & $\mathrm{MP}+\mathrm{MN}$ & 3.10 & & \\
\hline & \multirow{3}{*}{ MS } & $\mathrm{C}$ & 3.13 & \multirow{3}{*}{3.45} & \\
\hline & & MP & 3.47 & & \\
\hline & & $\mathrm{MP}+\mathrm{MN}$ & 3.73 & & \\
\hline & \multirow{3}{*}{ MP } & $\mathrm{C}$ & 3.13 & \multirow{3}{*}{3.34} & \\
\hline & & MP & 3.36 & & \\
\hline & & $\mathrm{MP}+\mathrm{MN}$ & 3.52 & & \\
\hline
\end{tabular}

2017 LSD05 ОБ.=0.157; LSD05A=0.119; LSD05B=0.099;LSD05C=0.110; LSD05AB=0.083; LSD05AC=0.088; LSD05 $\mathrm{BC}=0.093$.

2018 LSD05 ОБ.=0.169; LSD05A=0.113; LSD05 B=0.106; LSD05 C=0.110; LSD05AB=0.122; LSD05AC=0.126; LSD05 $\mathrm{BC}=0.122$.

2019 LSD05ОБ.=0.175; LSD05A=0.138; LSD05B=0.126; LSD05 C=0.130; LSD05AB=0.116; LSD05AC=0.188; LSD05 $\mathrm{BC}=0.106$.

2020 LSD05 ОБ.=0.206; LSD05 A=0.148; LSD05 B=0.151; LSD05 C=0.144; LSD05AB=0.153; LSD05AC=0.114; LSD05 $\mathrm{BC}=0.125$. 
Table 3. Yield of durum spring wheat, 2017-2020

\begin{tabular}{|c|c|c|c|c|c|}
\hline \multicolumn{3}{|c|}{ Version } & \multirow[b]{2}{*}{ Received, t/ha } & \multirow[b]{2}{*}{$\begin{array}{l}\text { Average for seed } \\
\text { treatment, } t / h a\end{array}$} & \multirow[b]{2}{*}{$\begin{array}{c}\text { Average for } \\
\text { fertilizer rate, } t / \text { ha }\end{array}$} \\
\hline Fertilizer rate (A) & $\begin{array}{c}\text { Seed } \\
\text { treatment } \\
\text { (B) }\end{array}$ & $\begin{array}{l}\text { Vegetation } \\
\text { treatment } \\
\text { (C) }\end{array}$ & & & \\
\hline \multirow{9}{*}{$\begin{array}{l}\overline{0} \\
\text { ర0 }\end{array}$} & \multirow{3}{*}{$\mathrm{C}$} & $\mathrm{C}$ & 2.06 & \multirow{3}{*}{2.28} & \multirow{9}{*}{2.48} \\
\hline & & MP & 2.25 & & \\
\hline & & MP+MN & 2.60 & & \\
\hline & \multirow{3}{*}{ MS } & $\mathrm{C}$ & 2.41 & \multirow{3}{*}{2.53} & \\
\hline & & MP & 2.58 & & \\
\hline & & $\mathrm{MP}+\mathrm{MN}$ & 2.65 & & \\
\hline & \multirow{3}{*}{ MP } & $\mathrm{C}$ & 2.44 & \multirow{3}{*}{2.63} & \\
\hline & & MP & 2.66 & & \\
\hline & & $\mathrm{MP}+\mathrm{MN}$ & 2.76 & & \\
\hline \multirow{9}{*}{ 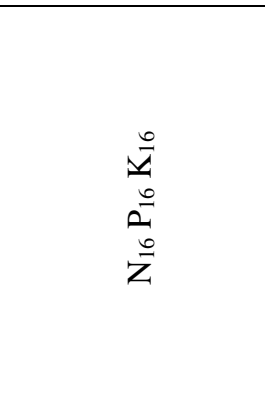 } & \multirow{3}{*}{$\mathrm{C}$} & $\mathrm{C}$ & 2.41 & \multirow{3}{*}{2.66} & \multirow{9}{*}{2.77} \\
\hline & & MP & 2.75 & & \\
\hline & & $\mathrm{MP}+\mathrm{MN}$ & 2.83 & & \\
\hline & \multirow{3}{*}{ MS } & $\mathrm{C}$ & 2.67 & \multirow{3}{*}{2.83} & \\
\hline & & MP & 2.89 & & \\
\hline & & $\mathrm{MP}+\mathrm{MN}$ & 3.03 & & \\
\hline & \multirow{3}{*}{ MP } & $\mathrm{C}$ & 2.68 & \multirow{3}{*}{2.83} & \\
\hline & & MP & 2.83 & & \\
\hline & & MP+MN & 2.94 & & \\
\hline \multirow{9}{*}{$\begin{array}{l}\tilde{a} \\
\tilde{n} \\
\tilde{n}^{2} \\
\tilde{z}\end{array}$} & \multirow{3}{*}{$\mathrm{C}$} & $\mathrm{C}$ & 2.84 & \multirow{3}{*}{3.01} & \multirow{9}{*}{3.06} \\
\hline & & MP & 3.02 & & \\
\hline & & MP+MN & 3.18 & & \\
\hline & \multirow{3}{*}{ MS } & $\mathrm{C}$ & 3.02 & \multirow{3}{*}{3.23} & \\
\hline & & MP & 3.27 & & \\
\hline & & $\mathrm{MP}+\mathrm{MN}$ & 3.44 & & \\
\hline & \multirow{3}{*}{ MP } & $\mathrm{C}$ & 3.01 & \multirow{3}{*}{3.21} & \\
\hline & & MP & 3.22 & & \\
\hline & & $\mathrm{MP}+\mathrm{MN}$ & 3.41 & & \\
\hline
\end{tabular}

2017 LSD05 ОБ.=0.146; LSD05A=0.115; LSD05B=0.117; LSD05 C=0.119; LSD05AB=0.127; LSD05AC=0.128; LSD05

$\mathrm{BC}=0.120$.

2018 LSD05ОБ.=0.129; LSD05A=0.130; LSD05B=0.136; LSD05C=0.134; LSD05 AB=0.220; LSD05AC=0.201;

$\mathrm{LSD} 05 \mathrm{BC}=0.112$.

2019 LSD05ОБ.=0.186; LSD05A=0.129; LSD05B=0.120; LSD05C=0.126; LSD05 AB=0.150; LSD05AC=0.146 LSD05BC=0.150.

2020 LSD05OБ. $=0.149$; LSD05 A=0.116; LSD05 B=0.112; LSD05 C=0.114; LSD05AB=0.128; LSD05AC=0.120;

$\mathrm{LSD} 05 \mathrm{BC}=0.128$.

The use of liquid mineral fertilizers also provides a reliable increase. Without the use of fertilizers the treatment of seeds with Megamix Seeds provides a yield of $2.39 \mathrm{t} / \mathrm{ha}$, with the Megamix Profi - $2.35 \mathrm{t} / \mathrm{ha}$, which is higher by 0.24 and $0.20 \mathrm{t} / \mathrm{ha}$ than the version where the seed treatment was not carried out on soft wheat crops and $2.53 \mathrm{t} / \mathrm{ha}$ and $2.63 \mathrm{t} / \mathrm{ha}$ with additions of 0.25 and $0.35 \mathrm{t} /$ ha on durum wheat crops (Table 2, 3).

When applying fertilizers at a generally higher yield level the use of the Megamix Seeds in seed processing together with the treatment of crops on average in versions provides a yield of soft wheat reaching $2.77 \mathrm{t} / \mathrm{ha}$ $\left(\mathrm{N}_{16} \mathrm{P}_{16} \mathrm{~K}_{16}\right)$ and $3.45 \mathrm{t} / \mathrm{ha}\left(\mathrm{N}_{32} \mathrm{P}_{32} \mathrm{~K}_{32}\right)$ and durum wheat of 2.83 t/ha $\left(\mathrm{N}_{16} \mathrm{P}_{16} \mathrm{~K}_{16}\right)$ and $3.23 \mathrm{t} / \mathrm{ha}\left(\mathrm{N}_{32} \mathrm{P}_{32} \mathrm{~K}_{32}\right)$. However, the level of these values is equivalent to the Megamix Profi seed treatment and amounts to $2.78 \mathrm{t} / \mathrm{ha}$ and $2.83 \mathrm{t} / \mathrm{ha}\left(\mathrm{N}_{16} \mathrm{P}_{16} \mathrm{~K}_{16}\right), 3.34$ and $3.21 \mathrm{t} / \mathrm{ha}\left(\mathrm{N}_{32} \mathrm{P}_{32} \mathrm{~K}_{32}\right)$, respectively for soft and durum wheat (Table 2, 3).

The use of vegetation agents significantly increases wheat yield.

The best yield on all seed treatment versions was achieved through double treatment with Megamix Profi (in the tillering phase) + Megamix Nitrogen (in the flag leaf phase). The maximum productivity was achieved by crops, the seeds of which are treated with Megamix Seeds against the background of $\mathrm{N}_{32} \mathrm{P}_{32} \mathrm{~K}_{32}$ fertilizers. This ensures the yields of $3.73 \mathrm{t} / \mathrm{ha}$ and $3.44 \mathrm{t} / \mathrm{ha}$ for soft and durum wheat crops respectively (Table 2, 3). As a result of four-year studies of the productivity of spring soft and durum wheat against the background of fertilizer application and using the Megamix system it was found that on versions with their use in the pre- 
treatment of seeds and vegetation processing the dynamics of dry matter accumulation increases, the photosynthetic potential increases, which leads to an increase in the yield of spring soft and durum wheat up to $3.73 \ldots 3.44 \mathrm{t} / \mathrm{ha}$, respectively.

\section{Conclusion}

The studies conducted over 2017-2020 revealed that spring wheat in the forest-steppe conditions of the Middle Volga region forms a photosynthetic potential of up to $1.031 \mathrm{mln} \mathrm{m}^{2} / \mathrm{ha}$. days (soft wheat) and $0.966 \mathrm{mln}$ $\mathrm{m}^{2} /$ ha. days (durum wheat), which ensures the formation of a balanced and full crop.

The systematic use of Megamix liquid mineral fertilizers as stimulating agents makes it possible to obtain high yields of spring wheat in the forest-steppe conditions of the Middle Volga region up to $3.73 \mathrm{t} / \mathrm{ha}$ (soft wheat) and $3.44 \mathrm{t} / \mathrm{ha}$ (durum wheat). The maximum yield is formed on crops where the seeds are treated with stimulating agents Megamix Seeds or Megamix Profi followed by the double treatment of crops with Megamix Profi 0.5 1/ha (in the tillering phase) + Megamix Nitrogen 0.5 1/ha (in the flag leaf phase) against the background of $\mathrm{N}_{32} \mathrm{P}_{32} \mathrm{~K}_{32}$ fertilizer application.

\section{References}

1. O.V. Ashaeva, M.B. Terekhov, Seeding rate as an energy-saving factor when cultivating durum spring wheat at different levels of nutrition, Resourcesaving techniques and technologies for cultivating crops: Proceedings of the All-Russian Scientific and Practical Conference (Ryazan. 1998) pp. 23-24.

2. A.N. Burunov, A.O. Strizhakov, V.G. Vasin, R.N. Bagautdinov, Indicators of photosynthetic activity of barley plants when using Megamix preparations in the forest-steppe of the Middle Volga region, In the collection: Current issues of feed production. State, problems, solutions (2019) pp. 157-162.

3. A.N. Burunov, Efficiency of Megamix microelement fertilizer used on spring wheat, Niva Povolzhya, 1(18), 9-12 (2011)

4. V.G. Vasin, A.N. Burunov, I.K. Kosheleva, A.A. Adamov, Formation of spring wheat and corn crops when using fertilizers and growth stimulants, Bulletin of Samara Scientific Center of the Russian Academy of Sciences, 20, 2(2), 320-329 (2018)

5. V.G. Vasin, A.N. Burunov, Influence of pretreatment of seeds with Megamix preparations on indicators of photosynthetic activity of crops and yield of spring wheat, Bulletin of Nizhnevolzhsky Agricultural University Complex: Science and Higher Professional Education, 1(37), 21-25 (2015)

6. B.A. Dospekhov, Field experiment methodology (with the basics of statistical processing of research results) (Agropromizdat, Moscow, 1985) $351 \mathrm{p}$.
7. M.G. Evdokimov, V.S. Yusov, B.M. Tatina, V.V. Andreeva, Grain formation and filling of durum spring wheat in forest-steppe conditions of western Siberia, Bulletin of Altai State Agrarian University, 11(133), 5-9 (2015)

8. S.B. Lepekhov. A.I. Ziborov. I.V. Golovanova, Influence of the Eco-stim preparation on the yield of soft spring wheat and quality indicators of durum spring wheat, In the collection: Agricultural science for agriculture. Collection of articles: in 3 books (Altai State Agrarian University, 2017) pp. 172-174.

9. A.G. Lozhkin, P.N. Malchikov, M.G. Myasnikova, Durum spring wheat in the forest-steppe zone of the Chuvash Republic, Grain farming of Russia, 4(58), 59-62 (2018)

10. V.I. Panasin, Microelements and crop (Kaliningrad, 1995) $282 \mathrm{p}$.

11. Ya. V. Peive, Agrochemistry and microelement biochemistry (Science, Moscow, 1980) 430 p.

12. Pesticides.ru: https:// www.pesticidy.ru/agrochemical/megamixuniversalnoe. (05.01.2021).

13. Pesticides.ru: www.pesticidy.ru/agrochemical/megamix-n10. (05.01.2021).

14. N.V. Podlesnykh, E.A. Kupryazhkin. V.A. Fedotov, Impact of seed processing and foliar dressing on the yield of durum winter wheat varieties in the Chuvash Republic, Materials of the International Scientific and Practical Conference of Young Scientists and Specialists (2015) pp. 39-45.

15. M.B. Terekhov, Spring wheat (Nizhniy Novgorod, 2000) $180 \mathrm{p}$.

16. M.B. Terekhov, O.V. Ashaeva, A.I. Abramov, Influence of nutritional level and seeding rate on the yield of durum spring wheat, $80^{\text {th }}$ anniversary of the breeder - geneticist academician Eliseev I.P. Materials of the anniversary conference (Nizhniy Novgorod, 1998) pp. 72-76.

17. Characteristics of plant varieties first included in the State Register of Breeding Achievements allowed for use in 2016: official publication (Rosinformagrotech, Moscow, 2016) 432 p.

18. S.N. Shevchenko, V.A. Korchagin, O.I. Goryanin, P.N. Malchikov et al., Production of high-quality grain of durum spring wheat in the Middle Volga region, Scientific and practical publication (2010) $38 \mathrm{p}$.

19. D. Shpaar, F. Ellmer, A. Postnikov, N.I. Protasov, Grain cultures (FUAinform, Mn., 2000) 421 p.

20. W. Bottger, W. Denecke, Pilzkrrankheiten im Getreide bekampfen, DLG-Mitt, 105(4), 341-343 (1990) 